\title{
Engineering factors as a decision model for choosing the type of renewable energy power plant establishment in Thailand
}

\author{
Songkrit Trerutpicharn ${ }^{1}$, Waranon Kongsong ${ }^{2}$, Kijbodi Kongbenjapuch ${ }^{3}$ \\ ${ }^{1,2}$ Department of Engineering Law and Inspection, Faculty of Engineering, Ramkhamhaeng University, Thailand \\ ${ }^{3}$ Faculty of Law, Ramkhamhaeng University, Thailand
}

\begin{tabular}{l}
\hline Article Info \\
\hline Article history: \\
Received Sep 13, 2020 \\
Revised Jan 23, 2021 \\
Accepted Feb 4, 2021 \\
\hline
\end{tabular}

Keywords:

Engineering Factors

Decision Model

Renewable Energy Power Plant

\begin{abstract}
The objective of this article is to propose the approach about engineering factors as a decision model for choosing the type of renewable energy power plant establishment in Thailand with supporting information to increase the number of renewable energy power plant establishments. Reducing energy consumption through the government and energy development from renewable energy plays an important role to strengthen the energy security for the country by increasing economic stability. To conserve the environment and reduce the use of energy from fossils, which is one of the main causes of global warming, the literature about acceptance, consisting of attitude related to usage, performance expectations, expectations of use, social influence, environmental support and government policy with analysis of decision models including interest in products, desire for products, product knowledge and the possibility to buy in the future to create energy security for the country, was reviewed. The government is making an effort to encourage the private sector to install electricity generation systems using renewable energy with support in various fields, including tax measures and the providing of various benefits to create investment incentives, such as academic information support, import duty exemption on raw materials for solar panels, support with funding loans, and revolving funds through financial institutions.
\end{abstract}

Copyright $(52021$ Institute of Advanced Engineering and Science. All rights reserved.

\section{Corresponding Author:}

Songkrit Trerutpicharn,

Department of Program Engineering Law and Inspection,

Ramkhamhaeng University,

2086 Hua Mak Subdistrict, Bang Kapi District, Bangkok, 10240, Thailand.

E-mail: songkrit.t99999@ gmail.com

\section{INTRODUCTION}

Currently, the world has a continuously increasing rate of fuel consumption. Many countries around the world are seeking sources. New forms of renewable energy can guarantee long-term energy security while also reducing the amount of carbon dioxide gas from the use of energy from fossils, such as oil, coal, etc. This is a significant cause of the global warming trends of major energy changes that are occurring with many factors affecting the future of energy in the world, which includes the points, aims and policies of the government in delivering enhanced prosperity. Also, it is necessary to find solutions to climate change problems. The climate change leads to the intention of the importance of governments to reduce greenhouse gas emissions (Greenhouse Gases or GHG) through the participation of countries (Nationally Determined Contributions or NDCs). Implementing policies to support NDCs will affect the supply and use of power of every part in society to support the economy to grow to achieve significant climate targets in accordance with the Paris Agreement. It is thus necessary to establish good policies and transparent, careful comparison between the expenses and benefits. These policies will help manage the risks of climate change and help society meet other goals that cover the matters of clean air and water and access to energy [1-3]. The outcomes can be considered at a reasonable price and society's economic growth. Technology continues to be important for improving the quality of life and finding solutions to climate change. The progress of science still affects energy use. There are new technologies and many devices that did not exist 5 to 10 years ago but now have a role. These are very important nowadays and have more impact, such as wind and solar technology resources and development of new petrol, diesel and electric cars. Overcoming both of the challenges of reducing the risk of 
changes in climatic conditions along with improving the quality of life is necessary through many new technological advances, although state policy and technology will have impacts on biological quality, energy, and the evolution of energy, but may cause disruption and instability, including unexpected effects [4-7]. Therefore, a comprehensive consideration process has been developed and implemented (Exxon Mobil, 2018) (Annual Energy Future Report 2018-2040).

In countries in Asia, whether it is China, India, Japan or ASEAN, each step is taken to increase the use of renewable energy in order to reduce greenhouse gas emissions in electricity generation while also shifting the rebalancing of energy by reducing dependence on natural gas and turning to the development of clean coal technology power plants. While many countries have set measures to reduce gas emissions such as carbon dioxide $\left(\mathrm{CO}_{2}\right)$, under the framework and guidelines of the United Nations Convention on Climate Change, the cost of electricity from solar, wind and other renewable energy has been continuously reduced. As a result, the proportion of renewable energy usage in Asia is also rising. For Southeast Asian countries, or ASEAN, although they are currently using natural gas, this produces the largest proportion of electricity. However, coal is still an important regional alternative due to the decrease of natural gas in the region and the increase in the price of LNG gas. The International Energy Agency (IEA) predicts that by 2040, ASEAN will have an additional electricity demand of 400,000 megawatts, of which $40 \%$ will be coal-fired power plants. This will cause the proportion of electricity generation from coal in ASEAN to increase from 32 percent at present to be 50 percent, and the proportion of natural gas usage will be reduced from 44 percent to 26 percent. At the ASEAN Ministers on Energy Meeting on 7 October 2015, it was stated that ASEAN will increase the proportion of renewable energy usage to 23 percent in year 2030 with the goal of reducing greenhouse gas emissions by 20 percent in a period of 10 years.

Demand increases every year in developing countries such as Thailand, and the country's power development plan 2018-2037 (PDP, 2018) states that the electricity generation in Thailand as of December 2017 totals 46,090 MW, and the forecast of demand for electrical energy shows that during the years 20182037, the electricity generation capacity must be increased by 77,211 megawatts by generating 56,431 megawatts with new power plants. In addition, there will be the release of the old power plants between 20182037 in the amount of 25,310 megawatts.

The government sector should encourage the private sector to install electricity generation systems using renewable energy by supporting various fields, whether it is through tax measures or the granting of various benefits to create investment incentives, such as providing academic information, exemption of import duty on raw materials, supporting loans for funds and working capital through financial institutions, and from the sufficiency economy philosophy of His Majesty King Bhumibol Adulyadej that paved the way for the use of renewable energy to be ready in many ways, both the landscape that is favourable in terms of policies to support more investment and the sustainability based on the philosophy of sufficiency economy.

Study method: This research uses a qualitative research approach in accordance with the document research guidelines by compiling documents and publications as shown in Figure 1. Related articles and research were analysed, and the following issues were synthesized: (1) use of renewable energy in Thailand, (2) Thailand's renewable energy potential, and (3) Choosing each type of renewable energy in Thailand, as shown in Figure 2, leading to the decision model chosen for organising each type of renewable energy power plant.

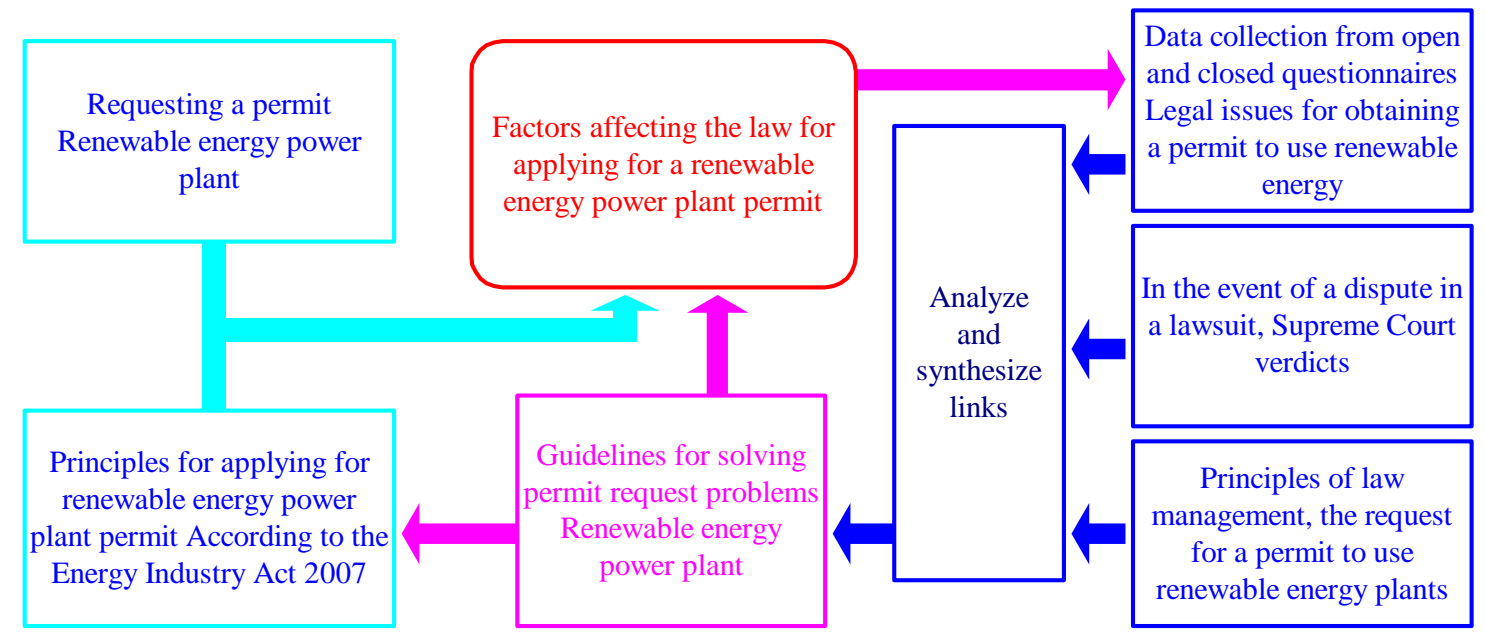

Figure 1. Conceptual framework of the research process according to the objectives 
Permit under the Energy Industry Act 2007 :

1. Electricity generation permit

2. Controlled energy generation permit (Por. 2)

3. Factory operating permit (Ror Ngo. 4)

4. Building construction permit (Or.1)

\section{Engineering factors}

1. Power plant design

2. Power plant installation

3. Power plant system testing

4. Power plant maintenance

5. Size of power plant installation area

6. Raw materials used for power generation

7. Location The place to install the power plant

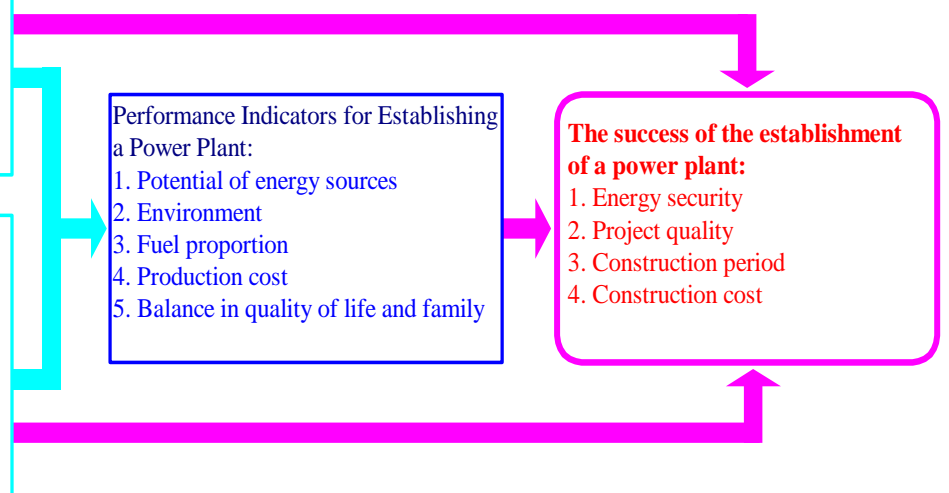

Figure 2. Research conceptual framework of the success of the establishment of a power plant

The results of the synthetic analysis and discussion of the results according to the issues: Renewable energy is energy that is derived from continuous and repeated energy flows. In an environment that benefits from renewable energy, there are many beneficial aspects, including protecting the environment and reducing pollution from the generation of electricity using fossil fuels derived from various petroleum products, while also reducing the import of these fuels from foreign countries. Furthermore, fuel energy also provides an interesting return on investment as well. The various types of renewable energy, such as sunlight, wind, biomass, water and hydrogen, are shown in Figure 3.

At present, the study and development of alternative energy involves academic studies [8-9], research, testing, development and demonstration, including the promoting and dissemination of renewable energy, which is clean energy with no effect on the environment, and is also an energy source that is available in various areas, such as wind, solar, biomass, etc. for generation. Moreover, the widespread use of efficiency and technical suitability with regard to the economy and society for urban and rural users in which the research and development of the said renewable energy is conducted also includes the development of tools, appliances and equipment for use [10-12]. The most efficient work also encourages the completed projects to be implemented and promoted and continue to be used appropriately.

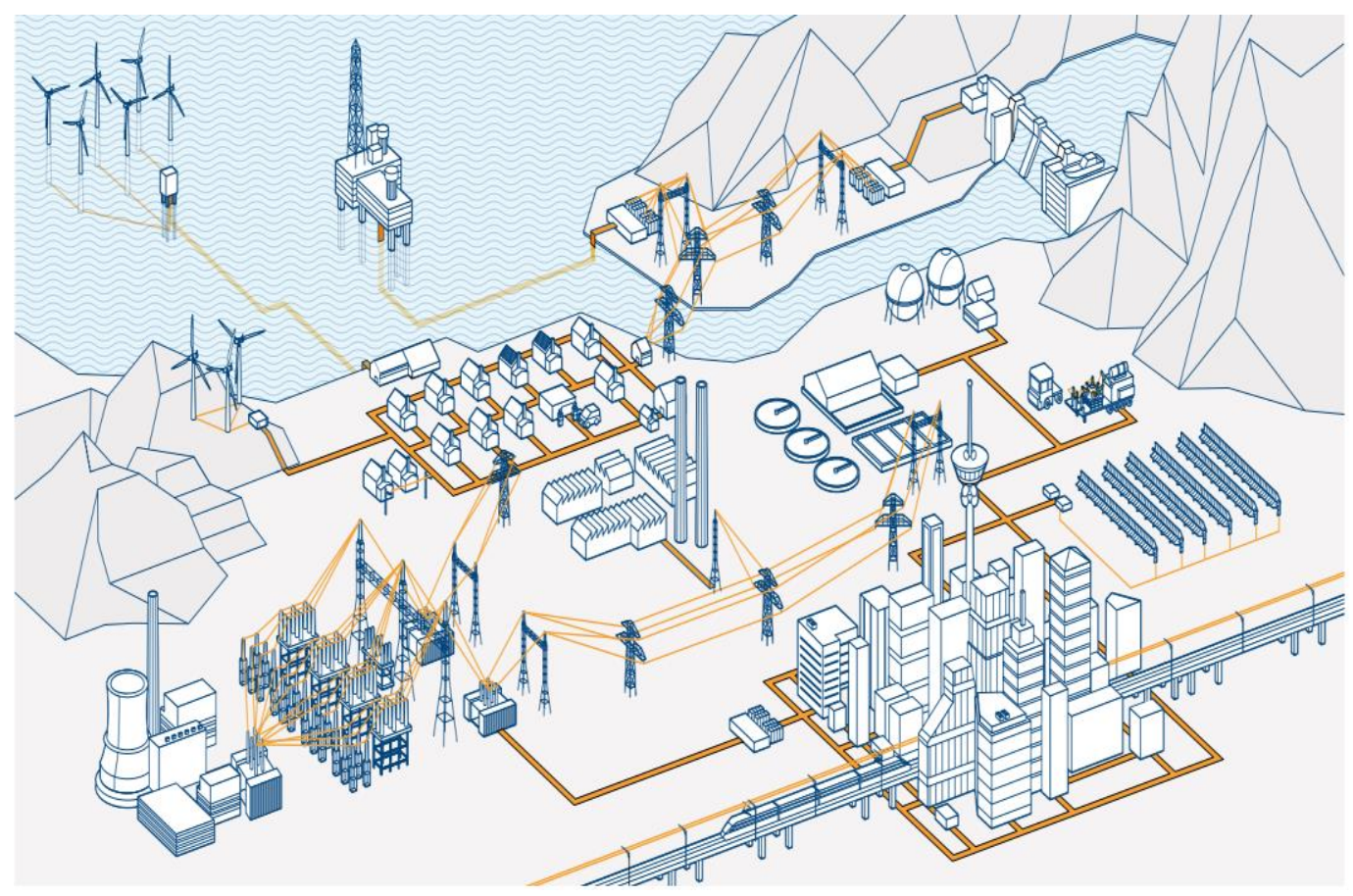

Figure 3. The Pilot Project of the Multicountry Observational Study Mission: Promoting GP with a Focus on Smart Grids and Green Energy in Thailand (@ 2PS design) 
The research results in power plant construction regarding the selection of a location are an important starting point. This process has to go through many steps, including the feasibility study of various issues, including the construction that requires a high budget [13-14], and therefore, all operations must be carried out prudently as they are related to the electrical system, the transmission system, and the environment. Additionally, the community chosen for the location of the power plant must be taken into account in terms of two main factors, which are 1) Engineering has enough space to build the utility power plant and environmental management near the coast that has water that is deep enough to be convenient for transportation. The plant for electricity generation is located near a large water source for use in the electricity generation processes and foundry systems, and the location is not far from the main power transmission system or high voltage station that can support the electric power generated. 2) Environmental measures to avoid rare natural resources conservation areas or irreplaceable species, such as watershed class 1A or watershed areas. There is still a perfect forest and forest conservation areas (Zone $\mathrm{C}$ ), so conservation areas and environmental protection areas should be avoided. Otherwise, if there is a need to use certain areas related to the power plant, there must be minimal impact and avoidance of locations that are important or sensitive to the feelings of the community, such as hospitals, schools, religious sites, archaeological sites, etc. and avoidance of the area where the community resides. However, the important thing for the project to be able to develop the power plant project is to receive acceptance and understanding from local communities, so that the community and environment and the power plants can exist together sustainably (Electricity Generation Division of Thailand, 2019).

\section{PROBLEMS OF USING RENEWABLE ENERGY IN THAILAND}

Currently, the condition of the global economy is expanding significantly and continuously, resulting in the excessive consumption of various resources, which results in the natural resources decreasing rapidly, especially those that are used as fuel, such as natural gas, oil, coal, etc. Regarding the economic driver of continuous growth, it is well-known that in this decade, the world experienced an oil price fluctuation of up to 150 dollars/barrel three times, which is different from the past. Therefore, the search for other types of power to replace it is an important matter, especially the research and development of alternative energy, such as biomass energy, solar power, wind power, and geothermal energy. The use of energy from waste and energy in the ocean waves, etc. is still limited and must take time for technological development for higher efficiency until leading to the generation of electricity for commercial use. Nowadays, there are many agencies that conduct studies [15-16], surveys, and experiments and analyse data continuously to prepare for energy consumption substitutes for use in Thailand, as shown in Figure 4.

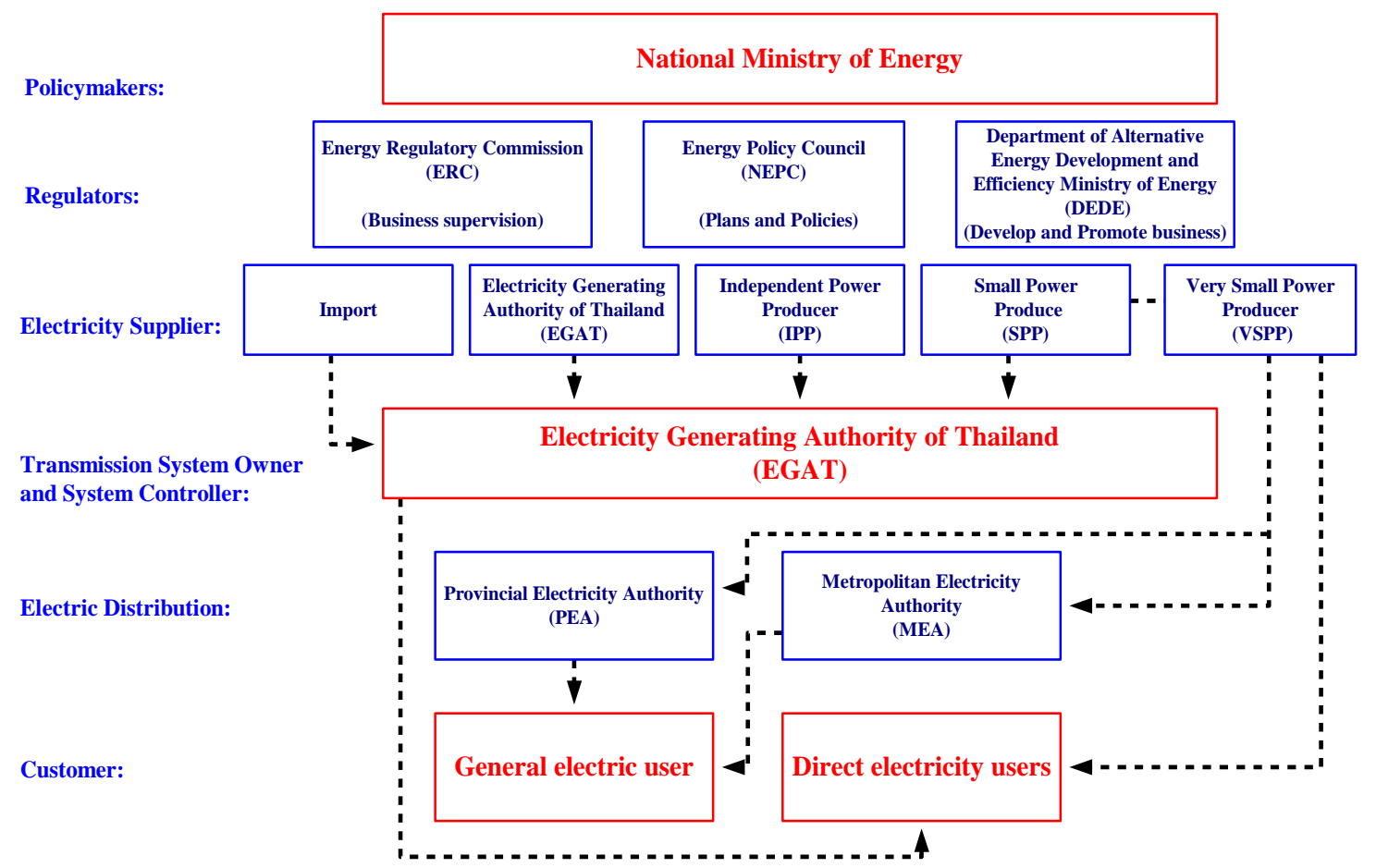

Figure 4. Various agencies involved in the electricity trading system of Thailand 
Types of alternative energy nowadays, energy is a major problem in the world, and this will have a severe impact on humankind. Increasingly, the Electricity Generating Authority of Thailand is another agency that attaches importance to finding solutions by conducting researches, surveys, and trials and following the technology seriously and continuously [17] to prepare for the introduction of alternative energy and new technologies in the field of alternative energy to Thailand. With regard to resources and the environment, the types of renewable energy can be classified as follows:

Solar power - Sunlight is a clean and abundant source of natural energy that will be available until the end of time because as long as the sun is still in this solar system, there will be energy sent from the sun to our earth. However, even if every living thing on Earth has exploited the energy directly from the sun on a continual daily basis, the amount that is being used is quite little compared to the amount of energy that can be acquired by humans; therefore, the application of solar power for various activities can be beneficial to development for many years. Even so, today, humans are still inventing new technology in order to use solar energy to create benefits as much as possible, either in the form of direct heat energy or via the transformation into electrical energy. In the future, technology related to the use of solar energy will be technology that is widely used more prevalently because, in addition to not having to incur the energy source costs, it will also be helpful with the reduction of the pollution of the world as well.

Solar power that hits the earth as light moves from the sun to the world as wave radiation. Electromagnetically, there are many wavelengths, also known as the spectrum of sunlight, which include the characteristics of the spectrum of the sun outside and inside the atmosphere, both in terms of the wavelengths of light that can be seen with the naked eye (visible light) and those which are not visible to the naked eye because they have short or long wavelengths of light, namely infrared, ultraviolet Gamma rays, X-rays, radio waves, etc. When light moves into the atmosphere of the Earth, which consists of atoms of gas, steam, clouds and various dust, some of it will cause collisions with the atoms of various things. These will result in the scattered light, some of which will hit the ground and reflect back into space, and there will be some that is absorbed by the atmosphere and clouds, resulting in the amount of light that is approximately $51 \%$ of the light hitting the Earth's surface being reflected back to $30 \%$ of the space and absorbed into the atmosphere. About 19 percent of the world's solar radiation is the amount of sunlight in the Earth's atmosphere.

The solar energy that moves through the atmosphere to the earth consists of energy from the rays of light that penetrate the atmosphere directly to the earth and the energy from the rays of light. From the distribution and internal reflection in the atmosphere, it is possible to divide the energy components into two types of sunlight on the earth, which are as follows.

1. Direct radiation, or beam radiation, is the radiation of solar energy that penetrates the layers of the atmosphere down to the surface without interacting with the atoms of any element in the atmosphere, which highly increases the value of the light intensity, making this type of radiation suitable for use with devices that require light. These Concentrators require high intensity solar radiation.

2. Diffused radiation, or scattered radiation, is the radiation of solar energy generated by collisions with atoms of various elements in the atmosphere, which cause the distribution of light and some reflection on the earth. The intensity of light from this type of radiation is much less than the direct radiation rays of light in nature. This light is suitable for use with devices that do not require high light intensity, such as solar cell systems, etc.

The proportion of radiation to the radiation distributed each day in each area will be uncertain, depending on the daily conditions of the weather in each area. The sum of the two types of radiation is called total radiation or global radiation. The vertical perpendicular to the area one unit outside of the Earth's atmosphere is known as the solar constant, which is equal to 1,353 watts per square metre. This constant is true, but actually, there may be fluctuations in the range of approximately 3.4 percent per year. However, in general, it is still commonly used as a constant that can cover all of the earth per year and can be calculated by considering that one year is equal to 365 days.

Wind power - Wind is a clean source of energy that can be used endlessly. At present, the use of the advantage of wind energy to generated electrical energy. To replace generation with energy from fossil fuels, especially in European countries, wind turbine technology has been developed to produce electricity commercially, in which each large wind turbine is able to generate electricity of 4 to 5 megawatts, which was developed to be largely improved and more efficient. In contrast, Thailand's research and development of wind power technology is still very limited. This may be because the wind energy potential in our country is not very high compared to other countries. However, if we have basic knowledge, we can apply wind power technology combined with other energy sources to ensure the stability of electricity generation. For example, the Laem Phromthep Power Station, Phuket, has experimented with using wind turbines to generated electricity 
together with solar cell systems and connecting them to the transmission system. Therefore, education, study, research and the development of wind energy technology is one method that will help reduce the energy consumption, which is another way to help Thailand reduce the import of energy resources from foreign countries.

Origin and type of wind: The primary cause of wind is the sun. When there is heat radiation from the sun to Earth, each position on the earth receives an unequal amount of heat, which causes temperature and air pressure differences. In each position, any area that has high temperature or low pressure, the air in that area will rise up. Colder air or higher air pressure that will replace the movement of this air mass is responsible for the creation of the wind, and from this movement of air masses, kinetic energy that can be applied to use the wind is created. This can be classified into various types according to the location where the temperature differences are located, as follows:

(1) Land and sea breezes are caused by the temperature differences between the sea and the shore, with the sea breeze occurring during the day because on the shore the temperature is higher than the area in the sea, causing wind from the sea to blow onto the coast. The land breeze occurs at night because the sea area has a higher temperature than on the shore, causing the wind to emerge from the shore and travel towards the sea.

(2) Mountain wind and valley wind winds are caused by temperature differences between the ridge and the valley, with the mountain breeze blowing down from the ridge at the top of the mountains to the valley at night due to the ridge area being in a higher area, and therefore cooler than the valley. The valley wind will blow from the ravine and ascend to the ridge, occurring during the day because the valleys are lower than the tops of the mountains, so the wind blows upwards. Along the height of the ridge, there is also a name for the wind according to the direction of movement in each season, such as 'monsoon', which means the wind that changes in the accordance with the change of season. Thus during the summer season, the wind will blow in one direction and will change to the opposite direction in the winter season (Department of Alternative Energy and Energy Conservation, 2016).

Biomass Energy - Biomass is an organic substance that is a source of natural energy which is obtained from living organisms, plants, agricultural waste, or waste from generation processes in the agricultural industry, such as rice straw, rice husk, bagasse, wood waste, palm fibre, palm shell, empty palm bunches, cassava residue and cassava rhizomes, coconut and coconut shells, yeast and waste, including industrial waste, agricultural products processing, ranch and various community waste, etc.

Biomass consists of carbon, hydrogen, oxidants, sulphur, and nitrogen, which can be transformed into energy because in the process of plant growth, plants use carbon dioxide with water and change energy from sunlight through photosynthesis resulting in starch and sugar being stored in different parts of the plant. Therefore, when using plants as fuel, we get energy, both directly and indirectly, from the plants, such as organisms that consume plants or waste from industrial factories, agriculture, and community waste, which is biomass energy in various solid, liquid and gas forms.

Because Thailand has extensive agriculture, agricultural waste materials such as rice husk, sawdust, and loggia as well as sugar cane and coconut meal are widely available (equivalent to at least 6,500 million litres of crude oil per year), which should be used as fuel generation of commercially available electricity. In the case of sawmills and large sugar mills, they may agree to provide materials for electric power for the electricity systems of the various power utilities in the country, which will help to make use of these energy sources in the country for the public to have more. This may include the use of firewood from planting projects and fast-growing trees in the millions of acres in the event that the government needs to reduce the quantity of cassava cultivation, sugarcane, etc. in order to solve the long-term marketing problems of both plants. Other biomass products that are currently used are ethanol from cassava, gas from firewood (gasifier), gas from fermentation, agricultural waste (bio-gas), waste, etc. If any material is commercially worthwhile, it may be used as fuel for electricity generation as well.

The utilisation of biomass energy can be used in both heat energy and electric power or fuel by using technology to generated energy from biomass (Biomass Energy Technology), including direct combustion (Direct Combustion), biomass gas generation (Gasification), Biogas generation, and generation of biofuels such as ethanol and biodiesel, etc.

Using plants as energy sources for the use of backup energy sources from sunlight is possible, because plants grow by relying on photosynthesis to create food, which is in the form of carbohydrates that accumulate in plants. That is to say that those plants are the best sources of solar energy because they can reserve solar energy by relying on chemical and physical changes for dozens or hundreds of years with no loss like other reserve energy sources. This is the energy accumulation model of sunlight in the form of biomass in nature.

Biomass energy sources make use of the energy from biomass as a source of fuel for combustion of wood, rice husk or manure to obtain heat energy, and in many developing countries, it is considered traditional. Biomass cannot be said to be a form of energy consumption that is either macro or commercial. Nowadays, 
when discussing the use of energy from biomass, it is often mentioned in terms of commercial energy consumption from biomass, especially as a fuel source in various industries. The nature of the use of energy from biomass is known as the use of energy from new biomass, in which the energy sources from biomass can be classified into two main categories, which are as follows.

Energy sources that are plant energy from biomass come from energy sources that are plants (Energy crops) and are cultivated as a source of energy. The energy sources from these plants can be divided into two types, namely:

(1) Woody plants (wood crops) can be found generally, especially according to their sources. Forests are the best sources of carbon dioxide in the atmosphere, and it can be said that during the growth of one tree, the amount of carbon dioxide that the tree absorbs from the atmosphere for use in photosynthesis will be close to or equal to the amount of carbon dioxide produced from utilising that tree to produce combustion. Therefore, using one tree from nature as fuel will not cause nature to lose balance in matters of pollution in any way. Nevertheless, the problem of pollution in the atmosphere is humans using energy from other sources, especially from recently dead remains, which cause the release of various toxic gases into the atmosphere, and those energy sources cannot be disposed of as waste by themselves, such as a tree, so the gases are released and accumulate in the atmosphere.

However, at present, the use of firewood or charcoal as a direct fuel in various industries is considered greatly reduced, especially in various industrial countries. This may be due to the result caused by the pollution that occurs in the atmosphere of the world today due to the amount of forests in the world that are always diminishing. Therefore, there is a new concept in the field of forestry, which is growing strong plants that are durable and fast-growing and do not have a direct purpose in generating these plants. These are sources of energy, but the purpose is to use wood for other general uses. The remaining wood chips, including sawdust, will be used as a source of energy in the form of heat energy and electric power, which is a concept that is different to the traditional concept that does not utilise the remaining fractions. This new concept of forestry is called short rotation forestry (SRF) and is very popular in the United States, Australia and New Zealand. In Europe, small plants are used in the form of scrub or scrub forest, which is called planting short rotation coppice (SRC).

(2) Agricultural plants (agricultural crops) are agricultural products that are currently being planted, such as sugarcane and corn, which are widely used as energy sources and are gaining attention around the world. The interest is the use of the potential contained in these plants to make liquid fuel. Other agricultural methods for using seeds as oil, such as sunflower, jatropha or legumes, can be adapted. The oil from these plants is biodiesel and can be used as a substitute for diesel obtained from the distillation of crude oil. This creates an energy source that is characterised as agricultural crops that will have the advantage to create a power source with the nature of the farm or the type of plantation as a grove because there is no complication in cultivation. Moreover, the cycle of space utilisation for cultivation is more flexible than that needed by other agricultural crops. Thus, the cycles of cultivation and harvesting are shorter.

Waste energy sources are available after the use of wood or harvesting of agricultural crops when agriculturalists have waste products such as wood chips, sawdust, cobs or the bark of various plants as well as animal faeces from livestock. These are considered as another form of biomass energy that can be used as an energy source. Waste products range from the household level, the community level to the industrial level; therefore, it can be seen that these energy sources are numerous, which can be classified into various types as follows:

1. Wood residues are a source of energy in the form of many solid biomasses from the forestry industry. Mostly, only the wood is used, and the rest are leaves and branches that cannot be used in industrial processes for processing, not including the sawdust, which can be used as an energy source both in the form of heat energy and electricity generation. In particular, the current electricity generation in Austria accounts for around 6 percent of the total electricity generation. Also, in the United States these pieces of wood are used as energy sources for electricity generation of over 6 gigawatts.

2. Agricultural wastes include corn, bagasse, rice husk, etc. Scraps from agricultural crops such as rice straw, wheat, and other wastes each year amount to billions of tonnes, and the energy is estimated to be 40 million terajoules. In the old days, straw was burned down from the fields or in the fields, which caused serious air pollution problems, but about ten years ago, in Europe, the burning of straw in the rice fields was prohibited. It is necessary to move the rice straw to store it in a dry place and once dried, it will be sent to continue to generated electricity. However, because the energy density of rice fang is 15 ja joules per tonne and 1 tonne of rice fang has a range of 6 cubic metres, problems in costs moving and storage are caused. Therefore, a new type of industry to solve this problem by compacting the straw like paper to make a density of about 1 tonne per cubic meter was created. This can help reduce and make the use of straw as a fuel more convenient than bagasse which occurs after the sugarcane squeezing of sugar factories. It also can be used as a fuel to generated electricity or used in their own factory, or in the case that a surplus of 
electricity is generated, it can be sold through the transmission line. Currently, sugar factories throughout the world have a combined power capacity of about 50 gigawatts.

3. Animal wastes are produced daily, and depending on the size of the animal, the animals will transfer large or small amounts of waste. Particularly, if raising animals in a farmable manner, enough waste can be collected from the animals that can be used as an energy source. This waste may be initially utilised in the form of animal manure, which is considered a reimbursement of energy to nature. On the one hand, plants can absorb some of the nutrients; however, nowadays, many countries around the world use these energy sources for commercial electricity generation, in which some power plants may have a generation capacity up to 40 - 50 megawatts with the use of agricultural waste as an energy source for electricity generation.

4. Municipal wastes may be commonly referred to as community waste. As a result of human consumption, waste or rubbish is left over. The average waste disposal in each household of the industrial countries is are more than 1 tonne per year, which accounts for 9 gigawatts of energy. This includes paper, glass scraps, metal scraps, and many others. One of these that is interesting is the rubbish that includes various organic substances that can be broken down by digestive processes or anaerobic digestion, and the result of most of these processes is methane gas, which can be used as an energy source, while other types of waste may be screened and separated for reuse (recycling), such as metal waste or that containing metal. In addition, the rest of the waste can also be used as an energy source for fuel to burn for combustion, which may avoid the use of the landfill method. By using this method over the years, the result is the generation of landfill gas (LFG), which can be also used as another source of energy. In addition, it can be used as fuel for electricity generation.

Biogas Energy - Biogas is produced by anaerobic processes, in which biogas is composed of approximately 50 - 80 percent methane $\left(\mathrm{CH}_{4}\right)$, and the other components are carbon dioxide $\left(\mathrm{CO}_{2}\right)$ and small amount of $\mathrm{H}_{2} \mathrm{~S}, \mathrm{~N}_{2}$, and $\mathrm{H}_{2}$, and thus, it can be used as a renewable energy. Currently, as the popular organic material created through this process, biogas is wastewater from industrial plants such as cassava flour factories, beer factories, canned fruit factories, etc., including wastewater from farm animals and their processing. The $\mathrm{CO}_{2}$ can be decreased by more than 80 percent to obtain $0.3-0.5$ cubic metres $/ \mathrm{kg}$ of biogas. The elimination of $\mathrm{CO}_{2}$ depends on the characteristics of each type of wastewater. Methane gas has a heat value of 39.4 mega joules $/ \mathrm{m} 3$ and can be used to replace 0.67 litres of the fuel oil, which is equivalent to 9.7 $\mathrm{kWh}$ of electrical power, for biogas system technology, biogas generation systems or wastewater treatment systems without use of oxygen.

The biogas generation system technology model, biogas generation system or wastewater treatment system without use of oxygen is used to eliminate sediment, and the excess oxygen from oxygen treatment systems is also used to eliminate sediment. Excess from oxygen treatment systems can reduce the volume and in the cold countries, biogas will be burned at $20^{\circ} \mathrm{C}$. The heat will be used to warm wastewater to be stable. About 37 years ago, the technology was widely used in treating industrial wastewater. This has increased significantly for two main reasons: reducing the cost of wastewater treatment and helping to reduce the use of substances to power the factories of biogas generation systems or non-oxygenated wastewater treatment systems, of which there are four main types, namely Anaerobic Filter (AF), Anaerobic Contact (AC), Upflow Anaerobic Sludge Blanket (UASB) and Anaerobic Fermentation Fluidized Bed (AFB). These high efficiency fermentation principles increase the amount of bacteria in the fermentation tanks.

AF tanks are packed with packing media that has a specific surface area that is highly cultivated and has high voids, with bacteria depositing mucus on the surface. In addition, it was found that there are a lot of bacteria. Regarding the advantages of this fermentation system, it is able to receive high amounts of organic matter, resistant to change of wastewater, and easy to control. However, this fermentation system has disadvantages: maintenance costs of the system are higher than other systems due to the price of materials for long-term filtration, and there are clogging problems. Therefore, the application and the amount of wastewater is not very high and in the design, this AF fermentation system requires filter media with spaces and high specific surface area and can contain only 10 - 20 percent of volume in order to prevent clogging problems.

As for the increase of bacteria by filtering, it can be said that it is the best way to increase the amount of bacteria. Furthermore, it also makes the wastewater that has been fermented by the best quality. However, this filter requires high power, and therefore it is not popularly applied in industry.

The AC fermentation tank, which relies on the principle of sinking sediment bacteria in the sedimentation tank, recirculates to fill in the tank. Fermentation causes the fermentation tank to have high bacterial sediment, thereby resulting in high efficiency, which is the main advantage of this fermentation system. Also, the construction costs of the fermentation system are not very high, but there are many disadvantages, including difficulty in design and supervision. This is because care must be taken to properly control the amount of bacteria in the system, which must be stirred and mixed in the fermentation tank. All the time, the sediment is difficult to sink, so it may be necessary to employ other equipment that helps to make the 
sediment sink better. This AC fermentation tank system is often used with high amounts of wastewater, which makes the construction costs of the system much lower in comparison to the AF fermentation system.

The UASB fermentation system is a more recent fermentation system developed by using the principle of creating conditions in the fermentation tank to properly allow granular bacteria to grow (Chapter 2 Alternative energy types, Chiang Mai University 2-14) and has a high amount in the fermentation tank. These bacteria granules are dense and have high cell volume. Therefore, this fermentation system has the high efficiency of this UASB fermentation system that is applied in the latter. Other fermentation systems have their many advantages, including the lowest construction cost, which is because it does not require agitation. The mixing and sedimentation tanks can accept a high amount of organic matter. However, this UASB fermentation system has the disadvantage of it being difficult to start up the system.

The AFB fermentation system has the principle of allowing small pellets to float freely in the fermentation tanks (Fluidisation), where bacteria are deposited on the surface of the mucus. This fermentation system can be said to be very effective, but there are disadvantages. It is difficult in design and supervision and has a high cost of both the fermentation system construction and supervision, due to the need for automatic rotation. The high and constant flow of water flows continually, which is why this type of fermentation system is not commonly used in the industry.

In addition to the principle of increasing efficiency by increasing the amount of bacteria in the fermentation tanks mentioned above, there are also methods for other applications that are used, including the Two-Stage Process, Thermophilic Operation, Hybrid Process, and Bacterial Filtration by Membrane Filtration. These two uses of fermentation tanks are connected in series. The first tank is called an acid fermentation tank; the second tank is referred to as a methane fermentation tank. The acid tank is 20 percent of the methane fermentation tank. It was found that this method (the Two-Stage Process) can reduce the size of the fermenter by about half or be able to receive higher amounts of wastewater at one time. This is because bacteria produce acids and methane. Methane production has different environmental requirements. Therefore, when the fermentation tank is separated into two tanks, the bacteria in both groups achieve higher efficiency.

Controlling the fermentation tanks at high temperatures is another way to increase their efficiency by controlling the temperature at $55{ }^{\circ} \mathrm{C}$, which is when the bacteria temperature is high and Thermophiles work best in applications. This principle is appropriate when wastewater is already at high temperature to avoid the cost of raising the temperature of the wastewater.

The use of mixed fermentation systems is one of the methods employed to increase efficiency and improve the stability of the higher fermentation systems such as AF-UASB, AF-AC, AC-UASB, AC-AFUASB fermentation, etc. The use of this mixed fermentation system may include the application of a two-stage fermentation system, which brings together the advantages of each system. AF-UASB will make the fermentation system easy at the beginning of operations because the filter medium acts as a trap for sediment bacteria in the system over the long-term operation of the system with the formation of granular sludge of bacteria.

Bio-fuel or Bio-Energy development is one of the main goals of the country's energy development strategy at present in order to reduce oil imports and be more self-reliant in terms of energy. Currently, according to the APEC-wide Foresight study, it was found that net oil import-dependency (oil import-oil export/total primary demand for oil) is higher than many other countries in the Asia-Pacific region and will increase from 75 percent of total oil demand in 2002 to 95 percent by 2020, with most of the energy in the transport sector accounting for 38 percent of the total energy use and 79.6 percent of the total energy use. All transportation energy is land transportation when the water crisis occurs. It has been severely affected, such as higher logistics costs, etc. At present, the government has a strategy to develop ethanol and biodiesel production to substitute for imported benzene oil and diesel, as it will be possible to use ethanol and biodiesel for transportation in about 5 years because the country of Thailand has a sufficient amount of raw material production space, which is an important component of bioenergy generation. Moreover, it is currently being used as mentioned for some useful power for transportation.

\section{PROBLEMS OF THE COUNTRY'S RENEWABLE ENERGY POTENTIAL}

Normally, the amount of reserves or potential to generated energy from natural resources with the potential value of energy of different types of substitutes will have a small change in value each year. The change will be noticeable only when there is a comparable value from information that has a far greater difference than that by many times and the known potential is still valuable [18-19]. Uncertainty depends on the reported numerical value and whether it is a complete survey value or a sampling value [20-22]. Therefore, the potential value proposed in this report presents the primary energy potential in the form of estimates greater than the actual quantity value.

1. Liquid biofuels from the collection and estimation of the amount of biomass that can be used to produce biofuels include liquids such as vegetable oil, for example palm oil, coconut oil and molasses from cassava. It was found that the amount of vegetable oil expected that can be used in the production of biodiesel is as 
follows: palm oil: 366.8 thousand tonnes of oil equivalent and coconut oil: 2.4 thousand tonnes of oil equivalent. Agricultural materials that can be used to produce ethanol are molasses: 98 thousand tonnes of crude oil equivalent and cassava: 306 thousand tonnes of oil equivalent.

2. Biogas production is conducted by fermentation of animal manure, community waste and industrial wastewater. Estimates show that the bio-potential from animal waste is: 307.0 thousand tonnes of oil equivalent, community waste: 0.4 billion tonnes of oil equivalent, and industrial waste: 230.4 thousand tonnes of crude oil equivalent. Currently, the biogas that is being used for energy generation is equal to 26.5 thousand tonnes of crude oil equivalent.

3. Solid biomass is from the collection and evaluation of biomass such as agricultural waste, firewood, and community waste by considering only the amount of biomass used in direct combustion or gas production. Synthetic fuel can be calculated as energy as follows: agricultural waste is 19,263.3 thousand tonnes of oil equivalent, firewood and charcoal is 0.8 thousand tonnes of crude oil equivalent, and municipal waste $3,431.9$ thousand tonnes of oil equivalent. Based on estimates of the use of biomass as energy, biomass is used as a solid that is equal to 10,516 thousand tonnes (Chapter 1 Renewable energy, Chiang Mai University 1-4, crude oil equivalent).

4. Imported coal will begin to play a role as a fuel in the power generation of Independent Power Producer (IPP) and Small Power Producer (SPP) proportion, which increased rapidly from $7.4 \%$ in 2003 to $17.2 \%$ in 2011.

5. energy has the potential of 527 thousand tonnes of crude oil equivalent. Energy from these sources is equal to 1.4 thousand tonnes of crude oil equivalent.

6. Hydrogen energy in Thailand is used for gas production. Hydrogen, which is a by-product of the petroleum and petrochemical industry, is burnt in some dry factories. As this fuel produces steam, the amount used is still very small.

7. Hydropower's potential is calculated from the electricity generating dams that currently have the potential that is $1,540.7$ thousand tonnes of oil equivalent. The energy generated from these sources is equal to $1,338.0$ thousand tonnes of oil equivalent.

8. Methane from coal mining was assessed for the methane potential from the coal in Mae Lamao basin, Mae Sot District, Tak Province, by drilling one production test well (depth of 317 metres) and two observation holes (depths of 293 metres and 308 metres). The methane flow rate in the test well production was tested by pumping water out of the borehole and allowing the gas to flow into the storage tank for 45 days. It appears that the gas flows into the tank trapped 19 litres in the first 10 days, but after another 30 days there was no gas coming out of the coal samples. From 24 borehole tests to test the release of methane from coal layers in the laboratory, it was found that there is a gas accumulated in charcoal content of 7 cubic feet/tonne, consisting of 60 percent methane, 28 percent nitrogen gas and 12 percent carbon dioxide. In conclusion, methane gas from the coal layer in the Mae Lamao basin is 325.4 million cubic meters Ft.

9. Natural gas is currently used in Thailand as the primary energy for generating electricity by accounting for over 60 percent of the total energy used to generate electricity. While the average demand for natural gas is more than 2,000 million cubic feet per day, with 77 percent of the total natural gas supply sold to EGAT, it is tied to independent power generation and small power generation to be used as fuel for electricity generation and sold to industrial plants. Moreover, $15 \%$ is used as raw materials in gas separation plants. Natural gas is used as a substitute oil that can save 10 billion baht per year in foreign currencies.

10. Nuclear power is reported from a small number of surveys providing current data about radioactive mineral resources. There was only one report in which radioactive minerals were found, but there was no estimate of the amount of reserves of radioactive minerals. Therefore, radioactive mineral energy sources have not yet been used in Thailand (Chapter 1 Renewable Energy, Chiang Mai University 1-5).

11. Shale is reported from the current survey to include 11 oil shale sources that have been found. Of the oil reserves in the country, there are 3,685.8 thousand tonnes of oil equivalent, and oil shale has not yet been used as a source of energy.

12. Solar power has the potential, when calculating from the area of $1.0 \%$ of the total area, of $554,070.6$ thousand tonnes of oil equivalent, with energy generation from these sources equal to 4.4 thousand tonnes of oil equivalent.

13. Oil Sands, according to the current survey, have no estimate of reserves in Thailand and thus, no oil sand has yet been used as an energy source.

14. Tidal energy has the potential equivalent to 0.001 thousand tonnes of crude oil equivalent. At present, no energy from the tides is used.

15. Wave energy has a potential is $0.5 \mathrm{k}$ tonnes of crude oil equivalent. Currently, no wave energy has been used. 
16. Wind energy potential is 12 thousand tonnes of crude oil, and wind turbines for 332.5 kilowatts are currently being installed.

\subsection{Power selection problems from each type of system}

1. Biogas Power Plant - The principle is that wastewater obtained from the generation process is used in fermentation in order to generate gas to generate electric power. Most of this wastewater can be obtained from flour mills and sugar factories, but the problem with this type of power plant is to find wastewater for fermentation to generate electric power because most of the factories will be constructed as power plants to generate electricity. In addition, the other problems is the numerous investors as the process of requesting a permit uses the method of purchasing wastewater to be added in the generation process in order to be sufficient for the generation capacity according to the license. However, when receiving a license they are unable to generate electricity as per the license granted because the wastewater supplier has requested a higher price or has provided distribution to other license owners.

2. Biomass Power Plant - The principle is to burn agricultural waste products such as rice stalks, rice husk shells, palm bunches, wood chips, and sawdust. The problem is similar to the biogas power plants, which is the need to request a license to have a fuel purchase contract. However, the contract will have a short period while the electricity sales agreement has a period of 25 years, and when the fuel sales contract has expired, the fuel sellers will be able to request a rise in fuel prices. Thus, the business person with unscheduled power plants will not be able to generate electric power under the electricity sales contract due to the generation cost that is higher, while the selling price of electricity remains the same. In addition, having several new biomass power plants in the same area will cause competition that is more challenging.

3. Waste-to-Energy Power Plant - The principle of this type of power plant is similar to the biomass power plants, but the material that is burnt is waste. As a result, there will be two problems.

The first problem is the waste acquisition. The investment in this business, which is not a waste land concessionaire, is to import the waste. Confidence in the future about having to burn waste for 25 years is quite difficult. Therefore, this type of power plant will be suitable for government agencies, such as those in municipalities, provincial administrative organisations, or organisations that accept the daily disposal of waste. The problem in the second part is the waste separation because all kinds of waste cannot be used as fuel for burning. Therefore, the rubbish of the people in the country is not able to selected with $100 \%$ separation of garbage, which will cause the fuel to not be able to generate electric power at full capacity or continue according to the electricity sales agreement effects in terms of value for investment.

Phacharaphon Peng-oung [5] studied the evaluation of alternative investment for a 3-megawatt community waste power plant by using real options. The objective of this research was to analyse the flexibility of the factors affecting construction investment. Community waste power plants must assess the risks that may occur when there are various factors that have changed with the analysis of return on the project with financial indicators combined with the Monte Carlo scenario. This was done by conducting a study of the construction of a 3-megawatt waste power plant, consisting of investment in waste power plants, waste incinerator technology, gasification and anaerobic degradation technology and fuel waste production, which has 10 choices. The results of the research showed that regarding investment in waste power plants, anaerobic digestion and the generation of the 3-MW Refuse Derived Fuel with net present value (NPV) and the rate of return, the Internal rate of return (IRR) was the highest at 120.59 million baht and $10.24 \%$. The results of the sensitivity analysis showed that the factors that have the most effect on investment in the construction of community waste power plants is the investment in each technology, the income from electricity sales and the income from waste disposal. From the results of the Monte Carlo situation in order to assess the project risk and conduct an analysis for investment flexibility by using the probability tree diagram, it was concluded that the most flexible choice is investment in anaerobic digestion technology and the generation of 4.5-MW Refuse Derived Fuel, which has a flexibility of 366.16 million baht.

4. Mini Hydro Power Plant - The generation of electricity from this type of power plant depends on the nature and season, which causes the main problem with this type of power plant. This is because it is necessary to find the location of the project that must have sufficient amounts of water available to generate electric power under the electricity sales agreement, which is not easy and results in quite a challenge for the project. Another problem is when the location of the water is available throughout the year and abundant, the undertaking of projects related to rivers and large canals is often opposed by local people, nature conservationists, and NGO groups.

5. Wind Power Plant - This type of power plant will have similar problems with the mini hydro power plants because it is a power station that depends on nature by using wind currents as the main source for generating electrical energy. In Thailand, where there is sufficient wind for generating electric power and the investment is worthwhile, this type of power plant business is limited to only two types of areas, the seaside and the mountains. 
The problem with the construction of a wind power plant near the sea is that the price of land by the sea is quite expensive because most projects there were built as resorts or luxury hotels, which causing it to not be worth the investment. Also, power plants often being opposed by nature conservationists and NGOs.

For mountainous areas, the sticking point is the legal issues because the mountain areas are usually a forest reserve where the projects. The overall problem of this project is one of the noise pollution and shadow flicker that occurs due to the large turbines spinning when the location of the project is near a community Therefore, there will be a problem regarding the complaints about the disturbances. such as the wind power plants cannot be approved. One project in the northeast region is the land used by ALRO in the project development. Until it is completed and the electricity distribution has been completed, it is land without a title deed. There are groups of people suing because the land is being incorrectly used with the Supreme Administrative Court's final verdict, in which the Supreme Administrative Court stated that the SorPhorKor Land is land that is only for farmers to benefit. It cannot be used for projects. Therefore, the government provides assistance using Article 44 because it is a project to generate electric power for the system for over 10 years, and over 14,000 million baht has already been invested [23].

6. Solar Power Plant - There are two issues of a solar power plant. The first is the area that is used for the project installation [24-25]. Currently, the area used for construction per one megawatt is about 10-12 rai of land with improved technology (Formerly, 15 - 20 rai of land was used in the first phase of the electricity sales project using solar energy). Nevertheless, there is still a problem regarding the use of large areas for solar power plant projects because it is necessary to find a place that is large enough for the generation of electricity under the power purchase agreement, and it should be land that is not far from the transmission line that will be used to connect to the system to distribute the electricity in the system. For the worthiness of the project and the area investment around the project area, there should not be any high buildings or tall trees that will overshadow the power generation panel because it will cause the generation efficiency to be decreased. Also, this type of solar power plant that must depend on nature and the seasons. This is a problem because for the location of the project in each area of the country, the intensity of the sunlight received to generate electricity is not equal, together with the cold season, hot season, and the time of the light to generate the electrical power are also not equal.

The second point is the understanding of the local people regarding solar electricity generation technology. There are still some villagers who have a misunderstanding that this type of power plant causes agricultural produce to not be as desired or causes it to fall unevenly according to the season.

Pitippee Ruammek [4] has studied the success factors for the development of sustainable solar energy projects. Solar energy is a clean energy resource that will never run out. By not polluting and not creating greenhouse gases, solar energy plays an important role in the country's energy security and helps strengthen economic stability through the promotion of environmental preservation and the reduction of the use of fossil energy, which is one of the main causes of global warming. Thailand has initiated projects and utilised solar energy widely from the household level, communities, businesses, and industries to the national level by the success factors of the project development. Sustainable solar energy consists of 1) location, 2) technology, 3) professional teams, 4) financing with low and stable costs, and 5) government policies and support.

Songkrit Trerutpicharn [26] conducted a study in Bangkok and perimeter by using the integrated research methodology combining quantitative research and qualitative research, with the topic studied being the establishment of a juristic person registered with the Department of Business Development, Ministry of Commerce. The sample included executives/managers of establishments. The sample size was calculated using the formula of Taro Yamane for 400 people by use of the specific selection method. Questionnaires were utilised to collect the data, and for the qualitative research, the key informants were nine academics involved in solar electricity systems by in-depth interviews. The tool used was an interview form. The statistics used for data analysis were descriptive statistics and reference statistics, which consist of percentage, average, standard deviation and multiple regression analysis. The objectives of this research were to study: 1) The acceptance and decision-making process for solar energy use of an establishment, 2) Performance of an establishment that chooses solar energy, and 3) Examination of the decision model for choosing the solar workplaces of the establishment. The results indicated that, when considering the Multiple Correlation Coefficient with step-bystep techniques, S.E. $=0.380$. Prediction standards from 10 predictive variables showed that six variables enter the equation by prioritising as follows: possibility to buy in the future $(\beta=0.227)$, state policy $(\beta=0.192)$, product attention $(\beta=0.174)$, expectation of use $(\beta=0.172)$, product knowledge $(\beta=0.137)$ and social influence $(\beta=0.117)$, which together can predict the variance of the performance of the enterprises in Bangkok and perimeter at $76.50 \%$ with statistically significance at $0.05(\mathrm{R} 2=0.765)$.

\subsection{Summary of problems caused by renewable energy businesses}


The summary of problems caused by businesses involving renewable energy power plants can be summarised as follows:

1. Overall problems, including problems with the power grid to be connected, problems with requesting licenses as shown in Table 1, and technical engineering problems [27-28].

2. Problems classified by type of renewable energy power plants, including fuel problems for gas power plants, biomass power plants, and biomass power plants from waste energy.

3. Problems regarding suitable locations due to the dependence on nature of small hydroelectric power plants, wind power plants, and solar power plants [29].

Table 1. Licenses and Certifications Required in Energy Industry Operations

\begin{tabular}{|c|c|c|}
\hline Approval/Permit/Certificate & Related Laws & Authorised Government Agency \\
\hline Permit for electric power industry & Energy Industry Act 2007 & $\begin{array}{l}\text { Energy Regulatory Commission } \\
\text { Ministry of Energy }\end{array}$ \\
\hline Controlled energy generation permit & $\begin{array}{l}\text { Energy Development and } \\
\text { Promotion Act } 1992\end{array}$ & $\begin{array}{l}\text { Department of Alternative Energy } \\
\text { Development and Efficiency } \\
\text { Ministry of Energy }\end{array}$ \\
\hline Factory permit & Factory Act 1992 & $\begin{array}{l}\text { Department of Industrial Works } \\
\text { Ministry of Industry }\end{array}$ \\
\hline $\begin{array}{l}\text { Building construction permit or building construction } \\
\text { notification form }\end{array}$ & $\begin{array}{l}\text { Building Control Act } \\
\text { 1979/Industrial Estate Authority of } \\
\text { Thailand Act } 1979\end{array}$ & $\begin{array}{l}\text { The Industrial Estate Authority of } \\
\text { Thailand (IEAT) } \\
\text { Ministry of Industry }\end{array}$ \\
\hline Investment promotion card & Investment Promotion Act 1977 & $\begin{array}{l}\text { The Board of Investment of Thailand } \\
\text { (BOI) }\end{array}$ \\
\hline
\end{tabular}

\section{THE LAWSUIT IN THE CASE OF THEP SATHIT WIND FARM COMPANY LIMITED POWER PLANT, CHAIYAPHUM}

Due to the electricity generated by Thep Sathit Company can be purchased by EGAT and sent to the Bannarong high voltage station to distribute the electricity generation of Thep Sathit Company, therefore it is not beneficial to farmers in the area implementing such reforms and citizens in areas that do not directly benefit in any way.

In the case of the Supreme Administrative Court, the judgment was upheld by the Central Administrative Court. It was ordered that the lease agreement of S.O.P. in the instalment of the wind turbines of the Thep Sathit Wind Farm Company Limited be cancelled because it is unlawful with the substance and interest in the judgment of Black Case No. Or. 1203/2009 and Red Case No. Or. 1728/2016 between Miss Wanwisa Klinsrisuk and 10 others, the prosecutor who sued the Secretary-General of the Agricultural Land Reform Office Defendant 1, the Board of Directors, Chaiyaphum Land, 2nd Defendant, and Thep Sathit Wind Farm Co., Ltd.

In this case, the Claimants No. 1-10 filed a lawsuit that the Claimants No. 1-10, who are citizens living in the Ban Rai Sub-district area, Thep Sathit District. Chaiyaphum Province, suffered damage due to the Chaiyaphum Land Reform Committee had resolved in the 4th/2009 meeting, held on 23 September 2009, to approve the Thep Sathit Wind Farm Company Limited to use the area to conduct the installation of wind turbines to generate electricity in the land reform area of Ban Rai Sub-district, Thep Sathit District, Chaiyaphum Province, in the amount of 38 rai. The lease period is for 3 years.

After the said resolution, the Office of Agricultural Land Reform (OCSC) in Chaiyaphum province proposed that the Secretary-General, Office of the Private Sector Commission consider and approve the Thep Sathit Wind Farm Company Limited to install wind turbines to generate electricity using wind energy when on 16 August 2010, after which the lease contract was made in bad faith, that is, the lease period is 27 years, which was previously was scheduled for 3 years, without the approval of the Secretary-General of SorPorChor.

In addition, the wind turbine installation business is still in the 1st floor B-basin, which is in the scope of reporting the environmental impact assessment, which must be approved by the Office of Natural Resources Policy and Planning and the National Environment Board, and the Council of Ministers of the Kingdom of Thailand will consider the permission to proceed with the project, but it turns out that the said project did not prepare the environmental impact assessment report and did not receive the consideration of the cabinet to use the space in any way. Therefore, the resolution of the Chaiyaphum Land Reform Commission and permission orders of The Office of the Secretary-General of the Ministry of Education are unlawful. 
In addition, the respondents at 1-10 agreed that when the wind turbine installation project generated electricity with wind energy in the area, the 1st floor B-basin area, is a long-term project that may affect consumption and the people living in the area of Ban Rai Sub-district Community, Thep Sathit District, Chaiyaphum, causing them to not be able to lead a normal life because of losing the depression Class 1B water, which is a natural resource that is abundant without pollution. However, there is no process for any discussion In the indictment, the defendant 1-10 requests the court to issue the following verdicts or orders:

(1) Withdraw the resolution of the Chaiyaphum Land Reform Committee from the meeting no. 4/2009 on 23 September 2009 that agreed to stipulate that the area of Ban Rai Sub-district, Thep Sathit District, Chaiyaphum, which is a land reform area, is an area for business. The wind turbine generates electricity and Thep Sathit Wind Farm Company Limited is allowed to use the area to operate the wind turbine installation business to generate electricity by a rental method.

(2) Order to suspend or revoke the contract to rent the area for installing wind turbines and generate electricity in Thep Sathit District, Chaiyaphum, which is a watershed level 1B, between the Secretariat of the S.K.A. and the accused Chaiyaphum Land Reform and Thep Sathit Wind Farm Company Limited until the preparation of the analysis report on the environmental impacts.

By which the First Administrative Court judge revoked the resolution regarding Chaiyaphum Land Reform Commission that was passed as a resolution in the meeting 4/2009, on 23 September 2009, for Thep Sathit Wind Farm Company Limited to use the area for the installation of wind turbines that generate electricity by a rental method.

However, the respondents appealed by requesting that the Supreme Administrative Court reverse the judgment of the Administrative Court. The first step is to dismiss the case.

In this case, the Supreme Administrative Court has settled the case by listening to the summary of the facts of the owner's defence, the amount and the verbal clarification accompanying the statements of the judiciary and considered all of the documents in the various legal cases and the regulations, etc. that are related to it, and the Supreme Administrative Court has considered that the case has issues that need to be diagnosed. The resolution of the Provincial Land Reform Commission Chaiyaphum in the meeting no. 4/2009 on 23 September 2009 agreed to stipulate that the area of Ban Rai Sub-district, Chaiyaphum Province, which is a land reform area, is the area of electricity turbine business and allow Thep Sathit Wind Farm to use the said area to carry out the installation of a business involving wind turbines generating electricity by lawful means of rental. Having considered that, in the beginning, there are issues to consider; firstly, whether the ALRO has the power to take the land in Ban Rai Sub-district, Thep Sathit District, Chaiyaphum province for use in the agricultural land reform or not. The ALRO is the owner and has the power that can be used in agricultural operations in the area of Ban Rai Sub-district, Thep Sathit District, Chaiyaphum.

In case of any issues, they must be further diagnosed. The wind turbine power generation business of Thep Sathit Wind Farm Company Limited is an activity that supports or is related to good reform for agriculture. Having considered this case, Thep Sathit Wind Farm Company Limited has submitted an application for permission to manage the land or real estate for use in businesses that supports or is related to agricultural land reform, with the objectives to operate the wind turbines and generate and distribute electricity for the Electricity Generating Authority of Thailand with the operating status located in Moo 2, Ban Rai Subdistrict, Thep Sathit District, Chaiyaphum, which is a land reform area according to Royal Decree determining land boundaries in the areas of Yang Klak Sub-district and Ban Rai Sub-district, Thep Sathit District, Chaiyaphum to be a land reform zone in 2009.

In addition, although the project was approved by the local community, including approval from the Farm Administration Organisation, and the applicant has initially studied the environmental impacts of the project including receiving promotional support for the generation of alternative energy (wind turbine farm project) from the Department of Alternative Energy Development and Efficiency; however, the main objective of the agricultural land reform is to help farmers to have arable land and to make land use happen.

The most useful part of the plan includes the arrangement of housing on that agricultural land by leasing, renting, or making use of it by the state providing assistance in agricultural career development and improvement of resources and factors of generation as well as generation and disposal for better results. The wind turbine electricity generation project of Thep Sathit Company with features as a public service is beneficial to the public, but the said business is to generate electricity to distribute to the Electricity Generating Authority of Thailand, which is not for the purpose of seeking profit for a service or directly related to the wellbeing of farmers in the economy and society in the land reform area in Ban Rai Sub-district, Thep Sathit District, Province Chaiyaphum.

Since the electricity generated by Thep Sathit will be purchased by the Electricity Generating Authority of Thailand and sent to Bannarong Electricity Station of the Electricity Generating Authority of Thailand in Bamnen Narong District, Chaiyaphum by using the $115 \mathrm{kV}$ power transmission line for distribution, the electricity generation of Thep Sathit Company is therefore not helpful for farmers in the land 
reform area. Moreover, there is no factual basis in the number of cases that Judge 1-10, and the people in the area can directly benefit from the electricity generation of Thep Sathit Company in many ways besides the establishment. The Power Development Fund is the only result of the implementation of the wind turbine project as according to the resolution. The NEPC has established this fund only for the procurement of finances to improve the quality of life of the people and the environment in the communities around the power plant that are affected by the power plant construction or electricity generation. Therefore, the wind turbine electricity generation project of Thep Sathit is not a service or business related to the well-being of the farmers in terms of the economy and society in the area of land reform, which does not conform to the characteristics of the provisions in Article 1.5 of the Notification of the Ministry of Agriculture and Cooperatives regarding the determination of other businesses that support or are related to agricultural land reform under Section 30, paragraph five of the Agricultural Land Reform Act 1975 with Amendment by the Royal Command and Reforms that involve Farming for Agriculture (No. 3) 2532 (Version 2).

Therefore, the resolution of the Chaiyaphum Land Reform Commission in the meeting no. 4/2009 on 23 September 2009 agreed to stipulate that the area of Ban Rai Sub-district, Thep Sathit District, Chaiyaphum, which is a land reform area, is an area for business. The wind turbines generate electricity and Thep Sathit Wind Farm Company Limited is allowed to use the area to operate the wind turbine installation to generate electricity by a rental method. Therefore, it is a resolution not like the law, and it is not possible to appeal the revocation of the Administrative Court's Chaiyaphum Land Reform Commission resolution in the meeting no. 4/2009 held on 23 September 2009 that approved the request regarding the area of Ban Rai Sub-district, Thep Sathit District, Chaiyaphum, which is a land reform area and a watershed level $1 \mathrm{~B}$ as according to the resolution. The cabinet agreed for it to be the area for the wind turbine electricity generation business and for Thep Sathit Wind Farm Company Limited to use the said area to operate wind turbine electricity generation by a leasing method. As for other requests, they should be lifted, and the Supreme Administrative Court agrees with the standing judgment.

\section{CONCLUSIONS}

With the awareness of global warming that requires reducing the amount of greenhouse gas emissions combined with the needs of the country, Thailand wants to reduce dependence on foreign energy imports. Based on government policy with various strategies in which the electrical power is specified in item 6 , these policies aim to increase the country's economic potential in the long term and to proceed to encourage additional power plant construction by the government and private agencies for both the use of fossil fuels and alternative energy sources using all kinds of methods with disclosure, transparency, fairness and friendliness to the environment together with cooperation with the neighbouring countries in energy development and Article 8. The Development and Promotion of the Utilisation of Scientific and Technological Research and Development and Innovation by promoting large national investment projects such as clean energy, rail systems, automotive production, electricity generation, water management and waste management.

The government has assigned the Ministry of Energy to develop the Power Development Plan 2018 2037 (Power Development Plan: PDP2018) with three priorities as follows: 1) Security in order to have stability covering the power generation system, power transmission system and power distribution system in each area and responding to the amount of electricity needed to support the National Economic and Social Development Plan, including considering power plants for stability at an appropriate level to support the event of an energy crisis. 2) The economy (Economy) must consider the costs. Optimum electricity generation promotes low-cost electricity generation to reduce the burden of electricity users and does not hinder development. The country's economy and society in the long term includes the preparation of the electrical system to enable competition to generate electricity, which will help increase the overall electricity generation efficiency of the country with electricity generation reflecting the real costs. 3). For the environment (Ecology), the environmental impacts must be reduced by supporting electricity generation from renewable energy and increasing the efficiency of the electricity system (Efficiency) in both electricity generation and electricity usage by developing network systems for Smart Grid electricity in the PDP2018 plan, which must be consistent with the country's economic development direction.

This has been prepared and projected by the Office of the National Economic and Social Development Board (NESDB) that has predicted the long-term economic growth of 3.8 percent per year, which has the following important principles: 1) A reliable allocation of generation capacity in order to sufficiently respond to electricity demand, 2) Consideration of allocating fossil fuel power plants as primary power plants and allocating the main power plants in each sector, taking into account the power plants according to the government promotion policy, 3) The reliable power distribution framework, and 4) Electricity generation for use and/or direct sales by defining the power generation framework from IPS.

The concepts, principles, and cutting models for decisions that influence the choice of renewable energy provide the supporting information to increase the number of establishments that will install power generation systems for power from renewable sources. To reduce energy use, the government is developing 
electricity from renewable energy; therefore, this plays an important role in creating the country's energy security by helping to strengthen economic stability, promote environmental preservation, and reduce the use of fossil fuels, which is one of the main causes of global warming. This can be achieved by studying the literature on acceptance, which consists of the attitudes related to use, the performance expectations, and the expectations of use of social influence regarding the environment.

Government support and policies with the analysis of decision models consist of interest in products, desire for products, knowledge of products, and the possibility of future purchases, and a model for the measurement system has been proposed. The balance sheet consists of important perspectives: finances, customers, and internal processes. Moreover, learning and the strengthening of confidence will maintain the energy supplies for the country from the said potential. Including problems in the business of renewable energy power plants from the application for a project permit, the problem was delayed than the planned plan. Causing damage to the operation of renewable energy projects in accordance with the regulations of the Energy Industry Act 2007, licenses under Section 47, 48, 50, 51 must be obtained from the Energy Regulatory Commission (ERC). The period according to the specified period, for example (1) a license to operate electricity production business Energy Regulatory Commission no need to seek an opinion from any agency for a period of 75 days (2) a factory license (Ror. Ngo. 4) for a period of 90 days (3) a construction permit for a designated building (Or. 1) and a construction certificate ( Or.6) a period of 45 days, Or.6 takes a period of 30 days (4) a controlled energy production license (Por. 2), a period of 120 days.

The government sector should encourage the private sector to install electricity generation systems using renewable energy by supporting various fields, whether it is through tax measures or the granting of various benefits to create investment incentives, such as providing academic information, exemption of import duty on raw materials, supporting loans for funds and working capital through financial institutions, and from the sufficiency economy philosophy of His Majesty King Bhumibol Adulyadej that paved the way for the use of renewable energy to be ready in many ways, both the landscape that is favourable in terms of policies to support more investment and the sustainability based on the philosophy of sufficiency economy. This will result in the future of solar electricity in our country with the light that has begun to be very bright and will slowly develop from the potential mentioned. Therefore, the government is making a strong effort to encourage the private sector to build renewable energy power plants through the support of various fields with tax measures and the granting of various benefits to create investment incentives, such as supporting academic research, exemption of import duty on raw materials, and arranging loans for funds and working capital through financial institutions, as well as others.

\section{REFERENCES}

[1] Ministry of Energy, Department of Alternative Energy Development and Efficiency Energy Conservation (2016) Energy Development and Investment Handbook, Substitute Set 2. Retrieved September 25, 2017, from http://escofund.ete.eng.cmu.ac.th/upload/webData/file/renew_manual/Solar_.pdf

[2] Ministry of Energy, Department of Alternative Energy Development and Efficiency Energy Conservation (2017) Power situation Jobs of Thailand. Retrieved 25 September 2017, from http://www.dede.go.th/dede/images/stories/stat_dede/sit_56/sit_aug.pdf.

[3] Electricity Generating Authority of Thailand (EGAT), "Asia increases energy use rotating work for global warming Natural gas reduction trend But still have to rely on the stone", 2018, from https://www.egat.co.th/index.php?option=com_content\&view=article\&id=1249:article-20151112$01 \&$ catid $=49 \&$ Itemid $=251$

[4] Pitipee Ruammake, "Factors of memory succeeded in developing sustainable solar energy projects", Journal of Management, Year 34, Issue 1 January - June 2014, Thammasat University, 2014.

[5] Phacharaphon Peng-on, "Assessment of alternatives for community-based 3 MW power plant waste by using Ariel Options", Master of Science in Science Work Technology and Work Management Program (Interdisciplinary Program), 2017.

[6] Yaowapa Chuparaphawan, “Accepting new innovation”, Bangkok, Odean Store Book, 2016.

[7] Watthanaphon Suwanao, "Factors affecting decision to build a power plant in Krabi province", Srinakharinwirot University Journal (Science and Technology) Year: 7, Issue: 14, 15-24, 2015.

[8] Sutamat Chantaraworn, "Marketing mix factors that affect the cutting interest in buying products on Facebook of the population in Bangkok", Master of Business Administration, Rangsit University, 2013.

[9] Aggelidis, P., \& Chatzoglou, D., "Using a modified technology acceptance model in hospitals", International Journal of Medical Informatics, 78, 2016.

[10] Hart, A.O., Nwibere, B.M. \& Inyang, B.J., "The uptake of electronic commerce by SMEs: A meta theoretical framework expanding the determining constructs of TAM and TOE frameworks", Journal of Global Business Technology, 6(1), 1-27, 2015.

[11] Hsieh, C.-H., Wu, C.-G., \& Hsu, C.-P., "Convergence or divergence: A comparison of acceptance and use of technology for smart phones and tablets", International conference on management of engineering \& technology (PICMET), 3084-3010, 2016.

[12] International Energy Agency, Solar energy perspectives. Retrieved October 18, 2013, from 
http://www.iea.org/publications/freepublications/publication/Solar_Energy_erspectives 2011.pdf

[13] Kaplan, Robert S., \& Norton David P., "The Balanced Scorecard : Translating Strategies into Action”, Boston : Harvard Business School Press, 1996.

[14] Walters, C. Glenn., "Consumer Behavior: Theory and Practice", Homewood, IL:Richard D. Irwin Inc., 1978.

[15] The Institute for the Promotion of Teaching Science and Technology, "Lesson 6: Alternative energy", Retrieved from http://www.scimath.org/socialnetwork/groups/viewbulletin/407-6?groupid=145, 2017.

[16] Venkatesh, V., Davis, G.B., \& Morris, M.G., "User acceptance of information technology", Toward a unified view MIS Quarterly, 27(3), 425-478, 2016.

[17] Wichit Malawet, Demonstration of electricity generation with integrated renewable energy system, Nakhon Si Thammarat Rajabhat University, Thailand, 2013.

[18] Kaplan \& Norton. STRATEGY MAPS. Massachusetts: Harvard Business School Press, 2004.

[19] Philip Kotler et al. Marketing Management 12th Edition. Edinburgh Gate: Pearson Education Limited, 2012.

[20] Özsungur, F. \& Hazer, O. Analysis of the Acceptance of Communication Technologies by Acceptance, 2018.

[21] Model of the Elderly: Example of Adana Province. International Journal of Eurasia Social Sciences, 9(31), 238-247.

[22] Rogers, Everett M. \& F. Floyd Shoemaker, Communication of Innovations: A Cross Cultural Approach. New York: The Free Press, 2004.

[23] Songkrit Trerutpicharn, "The decision model affecting to use of solar cell of industries in bangkok metropolitan administration and suburb", Journal of Social Science and Buddhistic Anthropology, Vol.5 No.3, 195-209, 2020.

[24] Chaiyan Thawarawan, Study of alternative energy for future industrial work, Journal of Education and Social Development Burapha University, 8 (2), 10-14, 2012.

[25] Patcharin Saichan, Application of solar energy to drive the absorbed cooling system in Thailand, King Mongkut's Institute of Technology North Bangkok Journal, 26 (3), 533-541, 2016.

[26] Songkrit Trerutpicharn, "Problems for Business of Renewable Power Plants in Thailand", Engineering Transactions, Vol. 21, No.2 (45) July-December, 168-174, 2018.

[27] Saktanong, W., \& Sansak, D., "Multi-level swell voltage control for minimising damage to an on-grid system", Indonesian Journal of Electrical Engineering and Informatics (IJEEI), Vol. 8, No. 2, 306-319, 2020.

[28] Trerutpicharn, S., Kongsong, W., \& Kongbenjapuch, K., "Problems for Business of Renewable Power Plants in Thailand", Journal of Engineering Transactions, Mahanakorn University of Technology, Vol.21, No.2 (45), JulyDecember, 168-174, 2018.

[29] Trerutpicharn, S., "The Decision Model Affecting to Use of Solar Cell of Industries in Bangkok Metropolitan Administration and Suburb", Journal of Social Science and Buddhistic Anthropology, 5(3), 195-209, 2020.

\section{BIOGRAPHY OF AUTHORS}

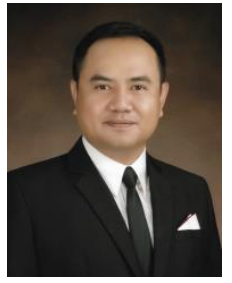

Songkrit Trerutpicharn received his Mater of Engineering in Electrical Engineering from King Mongkut's Institute of Technology Ladkrabang, Doctor of Business Administration from Western University. He was a lecturer for the Electrical Engineering in Faculty of Engineering, Mahanakorn University of Technology, Thailand. Currently, He is senior professional Thai license of engineer. He is also pursuing a PhD degree in Engineering Law and Inspection, Faculty of Engineering, Ramkhamhaeng University, Thailand. His research interests include Engineering Law, Law Enforcement, Transmission Line and Substation, High Voltage Engineering, Electrical Power System Analysis, Electrical System Design, Protection Devices, and Renewable Energy Power Plants.

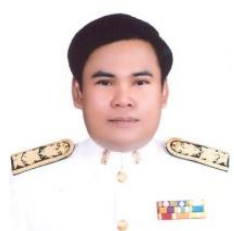

Waranon Kongsong received his Mater of Engineering in Civil Engineering from King Mongkut's University of Technology Thonburi, DODT in Engineering Organization, CEBU Doctors' University, Philippines, Doctor of Philosophy Program in Forensic Science and Thai Society, Magadh University, India and Doctor of Philosophy Program in Engineering, University of Southampton, UK. Currently, he is an Assistant Professor in Engineering for the Department of Program Engineering Law and Inspection, Faculty of Engineering, Ramkhamhaeng University, Bangkok, Thailand. His research interests include Structural Engineering, Civil Engineering, Concrete Work and Materials, Construction and Infrastructure Management, Engineering Organization, Engineering Law and Inspection, and Law Enforcement.

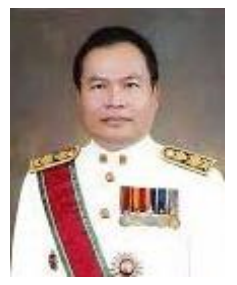

Kijbodi Kongbenjapuch received his D.E.A.de Sociologie (Paris VII U.), D.E.A. de Droit Public (Paris II U.), D.E.A. de Connaissance des Tiers Mondes (Paris VII U.), and Docteur en Droit (Paris II U.), Paris, France. Currently, he is a professor in law for the Faculty of Law, Ramkhamhaeng University, Thailand. His research interests include Public Law, Constitutional Law and Political Institution, Constitutional Provisions, Law Enforcement, and Problems of Enforcing Legal Provisions of Thai Constitutions. 